\title{
Pleuros ligų diagnostika
}

\author{
Dr. Rolandas Zablockis
}

VU Medicinos fakulteto Krūtinès ligų, alergologijos ir radiologijos klinika

Reikšminiai žodžiai: pleura, pleuros skystis, pleuritas, tuberkuliozė, neoplazija, biopsija.

Santrauka. Straipsnyje apžvelgiamos dažniausios pleuros ligos, jų priežastys, nagrinėjamos vaizdo tyrimo me-

todų, pleuros skysčio, pleuros bioptato tyrimų reikšmė atliekant diferencinę diagnostiką.

\section{SVARBIAUSIOS PLEUROS LIGOS}

Pleuros ligos dažniausiai pasireiškia skysčiu pleuros ertmejje. Jo gali atsirasti dèl pleuros, plaučiu ar kitų, ne plaučių, organų patologijos - žinoma apie 100 pleuros skysčio priežasčių. Patologiniai procesai pleuroje, taip pat ir skystis pleuros ertmèje, dažniausiai yra antrinio pobūdžio, t. y. kitų ligų komplikacija, be to, neretai skysčio pleuros ertmejje simptomatika esti vyraujanti. 1 lentelèje pateiktos skysčio pleuros ertmejje priežastys.

JAV atliktu tyrimu (ištirta 800 tūkst. pleuros skysčio punktatų) nustatyta, kad dažniausia pleuros skysčio priežastis - širdies nepakankamumas (apie 50 proc. visų atvejų). Kitos trys dažniausios priežastys: neoplazija, plaučių uždegimas ir plaučių arterijos tromboembolija. Šios keturios ligos lėmè apie 90 proc. visų pleuros skysčio atvejų [1].

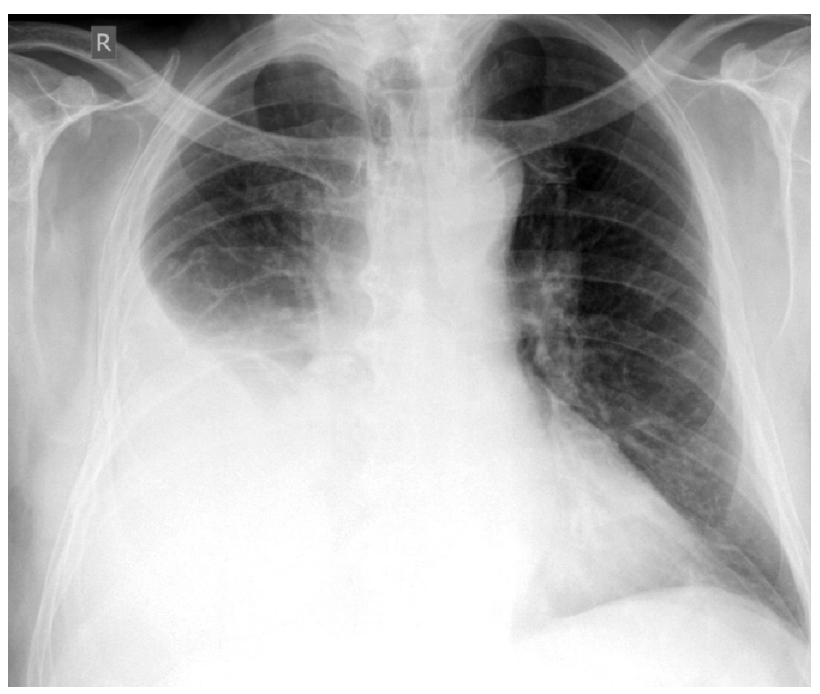

1 pav. SKYSTIS PLEUROS ERTMĖJE

\section{DIFERENCINĖ DIAGNOSTIKA}

Pasiūlyta įvairiausių pleuros skysčio diagnostinių tyrimo metodų, tačiau dalis jų mažai specifiški ar jautrūs, dalis jų - brangūs ir gali būti atliekami tik specializuotose laboratorijose. Nustatyti pleuros skysčio priežasties atlikus įvairius pleuros skysčio ir invazinius tyrimus nepavyksta 5-20 proc. atvejų [1, 2].

Pleuritui būdingi trys klinikiniai simptomai: kosulys, dusulys ir pleurinio pobūdžio skausmas. Šie simptomai gali pasireikšti pavieniui ar kartu. Deja, jie mažai specifiški, todèl menkai padeda nustatyti skysčio pleuros ertmèje kilmę.

\section{VAIZDO TYRIMŲ METODAI}

Stovinčiam tiriamajam rentgeniniu tyrimu galima nustatyti skysti pleuros ertmeje, kai jo yra daugiau nei 200-300 ml. Elis Demazo (Ellis Demoisseau') linija matyti, kai skysčio pleuros ertmèje yra daugiau nei $500 \mathrm{ml}$. Gulinčiam ant šono (laterograma) ligoniui galima nustatyti ir mažesnị kiekị pleuros skysčio - apie 100-150 ml [1, 3].

Plaučiu parenchimos infiltratas ir skystis pleuros ertmejje nustatomas plaučių uždegimo, plaučių arterijos tromboembolijos, bronchogeninès karcinomos, tuberkuliozès (TB), Dreslerio sindromo, kasos uždegimo, sisteminès raudonosios vilkligès ar kitos autoimuninès ligos, virškinimo organų patologijos, vaistų sukeltos pleuropulmoninès ligos atvejais [1].

Jei pleuros skysčio yra daugiau kaip $1500 \mathrm{ml}$ ir tarpuplautis nepasislinkęs ì priešingą skysčiui pusę, reikia ittarti šias būkles [4]:

- pagrindinio broncho neoplaziją ir plaučio subliūškimą;

- piktybinę mezoteliomą;

- plaučio navikinę infiltraciją, kuri rentgenogramoje atrodo kaip didelis kiekis pleuros skysčio. 
1 lentelè. SKYSČIO PLEUROS ERTMĖJE PRIEŽASTYS [1]

\begin{tabular}{|c|c|}
\hline I. Pleuros skystis transudatas & F. Akušerinès ir ginekologinès ligos \\
\hline A. Stazinis širdies nepakankamumas & 1. Kiaušidžių hiperstimuliacijos sindromas \\
\hline B. Kepenų cirozè & 2. Vaisiaus pleuritas \\
\hline C. Nefrozinis sindromas & 3. Pogimdyminis pleuritas \\
\hline D. Viršutinės tuščiosios venos obstrukcija & 4. Meigso sindromas \\
\hline E. Fontano procedūra & 5. Endometriozė \\
\hline F. Urinotoraksas & G. Kolagenozès \\
\hline G. Peritoninè dializè & 1. Reumatoidinis pleuritas \\
\hline H. Glomerulonefritas & 2. Sisteminė raudonoji vilkligė \\
\hline $\begin{array}{l}\text { H. Glomerulonefritas } \\
\text { I. Miksedema }\end{array}$ & 3. Vaistų sukelta vilkligè \\
\hline J. I pleuros ertmę patekęs likvoras & 4. Imunoblastinè limfadenopatija \\
\hline $\begin{array}{l}\text { J. I pleuros ertmę patekęs likvoras } \\
\text { K. Hipoalbuminemija }\end{array}$ & 5. Sjogreno sindromas \\
\hline $\begin{array}{l}\text { K. Hipoalbuminemija } \\
\text { L. Sarkoidozė }\end{array}$ & 6. Seiminè Viduržemio jūros karštinè \\
\hline $\begin{array}{l}\text { L. Sarkoidozė } \\
\text { II. Pleuros skystis eksudatas }\end{array}$ & 7. Churg-Strauss sindromas \\
\hline $\begin{array}{l}\text { II. Pleuros skystis eksudatas } \\
\text { A. Neoplazija }\end{array}$ & 8. Wegenerio granulomatozè \\
\hline & H. Vaistu sukeltos pleuros ligos \\
\hline & 1. Nitrofurantoinas \\
\hline $\begin{array}{l}\text { 2. Mezotelioma } \\
\text { 3. Küno ertmių limfoma }\end{array}$ & 2. Dantrolenas \\
\hline $\begin{array}{l}\text { 3. Kūno ertmių limfoma } \\
\text { 4. Su piotoraksu susijusi limfoma }\end{array}$ & 4. Skalsių alkaloidai \\
\hline $\begin{array}{l}\text { 4. Su piotoraksu susijusi limfoma } \\
\text { B. Infekcinés ligos }\end{array}$ & 5. Amiodaronas \\
\hline $\begin{array}{l}\text { B. Infekcinès ligos } \\
\text { 1. Bakterinè infekcija }\end{array}$ & 6. Interleukinas-2 \\
\hline $\begin{array}{l}\text { 1. Bakterinè infekcija } \\
\text { 2. Tuberkuliozė }\end{array}$ & 7. Prokarbazinas \\
\hline $\begin{array}{l}\text { 2. Tuberkuliozè } \\
\text { 3. Grybelinè infekcija }\end{array}$ & 8. Metotreksatas \\
\hline $\begin{array}{l}\text { 3. Grybelinè infekcija } \\
\text { 4. Parazitinè infekcija }\end{array}$ & 9. Klozapinas \\
\hline 4. Parazitinè infekcija & I. Kitos ligos ir būklès \\
\hline 5. Virusinè infekcija & 1. Asbesto poveikis \\
\hline C. Plaučiu embolija & 2. Po plaučiu transplantacijos \\
\hline D. Virškinamojo trakto ligos & 3. Po kaulų čiulpų transplantacijos \\
\hline 1. Kasos ligos & 4. Geltonujju nagų sindromas \\
\hline 2. Podiafragminis abscesas & $\begin{array}{l}\text { 5. Sarkomaze } \\
\text { 6. Uremija }\end{array}$ \\
\hline 3. Kepenų abscesas & 7. „Surakintas“ plautis \\
\hline 4. Blužnies abscesas & 8. Jonizuojančiosios spinduliuotés poveikis \\
\hline 5. Stemplès perforacija & 9. Skendimas \\
\hline 6. Po pilvo operacijos & 10. Amiloidozė \\
\hline 7. Diafragminè išvarža & 11. Kalcio papildai piene \\
\hline 8. Endoskopinis varikozių sklerozavimas & 12. Elektros nudegimas \\
\hline 9. Po kepenų transplantacijos & 13. Ekstramedulinè hemopoezė \\
\hline E. Širdies ligos & 14. Tarpuplaučio cistos plyšimas \\
\hline 1. Aortos ir vainikinių arterijų jungčių operacija & 15. Üminis kvèpavimo sutrikimo sindromas \\
\hline 2. Dresslerio sindromas & $\begin{array}{l}\text { 16. Wipplio liga } \\
\text { 17. Jatrogeninis pleuros skystis }\end{array}$ \\
\hline 3. Perikardo ligos & J. Hemotoraksas \\
\hline 4. Plaučiu venų stenozė po kateterinės abliacijos & K. Chilotoraksas \\
\hline
\end{tabular}

Krūtinès ląstos ultragarsinis tyrimas yra informatyvus, paprastas, neinvazinis, nekenksmingas ligoniui ir tyrëjui. Jis itin svarbus nustatyti, ar pleuros ertmëje yra skysčio, koks jo kiekis, ar skystis inkapsuliuotas ar neinkapsuliuotas, kokia to skysčio struktūra, padeda saugiau atlikti invazines procedūras. Pleuros skysčio kieki apytiksliai galima nustatyti pagal echogeninę zoną, skiriančią pasieninę pleurą nuo plaučių. Jei ši zona didesnè nei $20 \mathrm{~mm}$, - skysčio pleuros ertmèje yra apie $1500-2000 \mathrm{ml}$, jei $10-20 \mathrm{~mm}$, - jo yra apie $200-300 \mathrm{ml}$, jei $2-5 \mathrm{~mm}$, - apie $100-150 \mathrm{ml}$. Ultragarsinis tyrimas padeda nustatyti ir mažesni nei $150 \mathrm{ml}$ pleuros skysčio kieki, padeda atskirti pleuros ertmès skystị nuo solidinių struktūrų. Vis dèlto ultragarsinis krūtinès ląstos tyrimas turi ir trūkumų, nes sunku ịvertinti plaučiu parenchimos ir tarpusieninès pleuros pokyčius $[1,5]$.

Spiralinè krūtinès ląstos kompiuterinè tomografija (KT) padeda atskirti pleuros ir plaučiu parenchimos ligas, padeda geriau ivertinti tarpuplaučio limfmazgiu pažeidimą, plaučiu parenchimos, pleuros, krūtinès ląstos sienos, kaulinių struktūrų, tarpuplaučio pokyčius, patologinio proceso lokalizaciją ir išplitimą, skysčio pleuros ertmèje pobūdį. Deja, krūtinès ląstos KT negalima nustatyti, ar pleuros pokyčiai susiję su alsavimu, sunku ivvertinti diafragmos pokyčius [4]. Neoplazijos KT požymiai: mazginis ar nemazginis plautinès ar pasieninès pleuros sustorèjimas, hemitorakso apimties sumažèjimas, skystis pleuros ertmèje, tarpskiltiniu tarpu, diafragmos infiltracija bei tarpuplautinès pleuros pažeidimas. Mezoteliomos atveju kompiuterinèje tomogramoje matomi pokyčiai yra nespecifiniai. Dažniausiai nustatoma sustorejusi pleura (94 proc.) ir skysčio pleuros ertmejje (76 proc.). Pleuros sukalkejjimas ir plokštelès, kurios rodo buvusi kontaktą su asbestu, netolygus pleuros kontūras, mazginiai pleuros pokyčiai nustatomi tik 16 proc. ligonių. Vèlyvose stadijose nustatoma diafragmos, krūtinès ląstos sienos, perikardo, tarpuplaučio, limfmazgiụ pažeidimas $[6,7]$. 


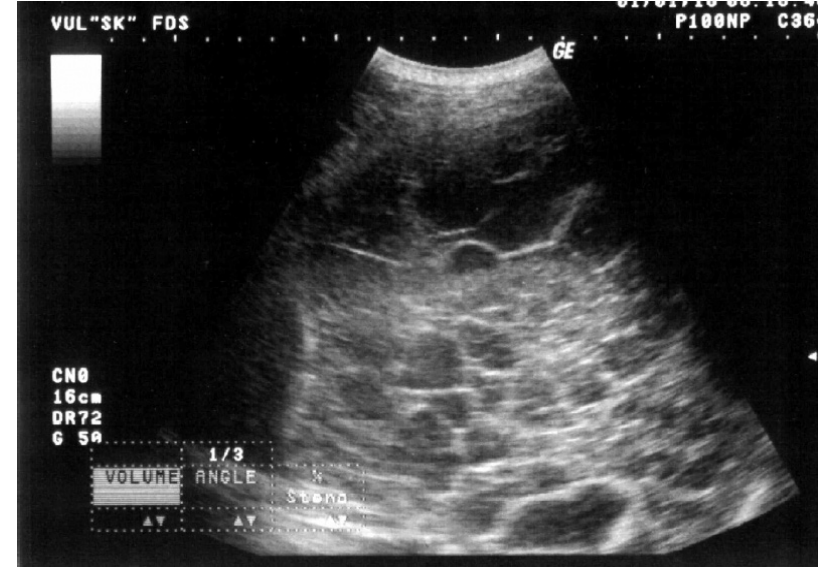

2 pav. DAUGYBIŠKAI INKAPSULIUOTAS SKYSTIS PLEUROS ERTMĖJE

Atliekant magnetinio rezonanso tyrimą (MRT) galima labai gerai matyti pleuros pokyčius, atskirti solidines struktūras nuo skysčio pleuros ertmejje, įvertinti diafragminès pleuros ir krūtinès sienos pokyčius. Tačiau nèra kontrastinès KT ir MRT lyginamųjų tyrimų, todèl sunku spręsti, ar MRT pranašesnis tyrimas nei $\mathrm{KT}[4,6]$.

\section{PLEUROS ERTMÉS PUNKCIJA IR PLEUROS SKYSČIO TYRIMŲ VERTINIMAS}

Tolesnei pleurito diferencinei diagnostikai būtina diagnostinè pleuros ertmès punkcija. Pirmiausia vertinamas pleuros skysčio kvapas (dvokiantis būdingas pleuros empiemai, sukeltai anaerobinių bakterijų), spalva, skaidrumas. Nereikètų pervertinti pleuros skysčio spalvos pokyčių. Svarbu kraujingas (hemoraginis pleuritas ir hemotoraksas), pūlingas ar chiliozinis skystis. Kiti pleuros skysčio atspalviai diferencinès diagnostinès reikšmès neturi [8, 9]. Kitas pleuros skysčio vertinimo etapas - nustatyti, ar skystis yra transudatas ar eksudatas [1, 11]. Transudato ir eksudato diagnostikos kriteriju yra ịvairių, skirtingo jautrumo ir specifiškumo, bet nè vienas nesiekia šimto procentų. 1972 m. R. W. Laitas su bendradarbiais [1] paskelbẻ diagnostinius eksudato ir transudato kriterijus, kuriais vadovaujamasi iki šiol daugelyje pasaulio klinikų. Ek-

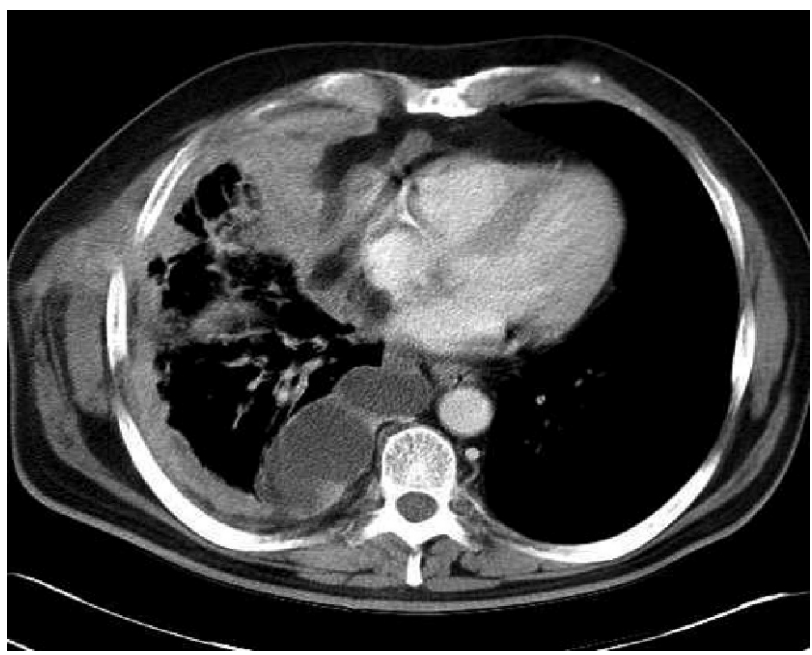

4 pav. PIKTYBINÉ PLEUROS MEZOTELIOMA

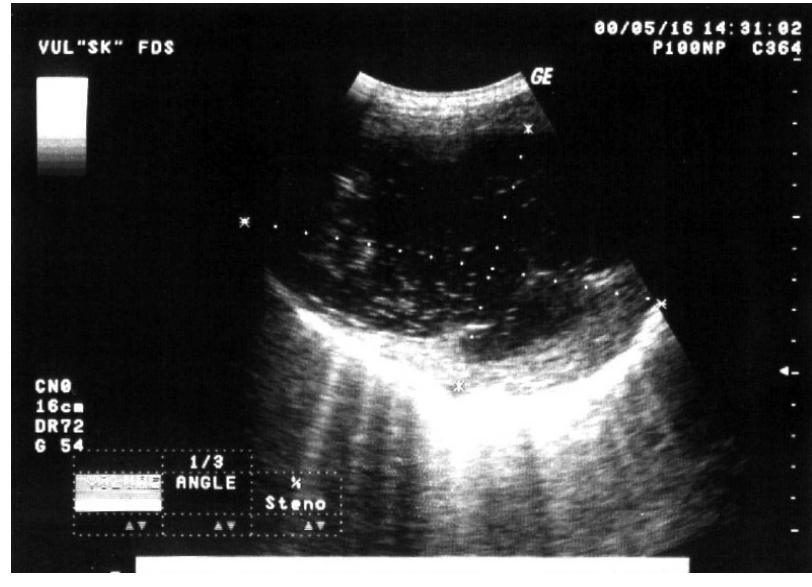

3 pav. PLEUROS EMPIEMA

sudatui būdingas bent vienas iš šių kriterijų:

- pleuros skysčio ir kraujo serumo baltymo santykis didesnis nei 0,5 ;

- pleuros skysčio ir kraujo serumo laktatdehidrogenazès (LDH) santykis didesnis nei 0,6 ;

- pleuros skysčio LDH aktyvumas didesnis nei $2 / 3$ kraujo serumo LDH aktyvumo viršutinès normos ribos.

Jei nè vieno iš šių kriterijų nèra, pleuros skystis transudatas. R. W. Laito kriterijų jautrumas siekia 98 proc., o specifiškumas - 83 proc. [2].

Nustačius, kad skystis yra transudatas, toliau ji tirti netikslinga. Reikia aiškintis, kuri iš dažniausių keturių priežasčių: širdies nepakankamumas, kepenų cirozė, nefrozinis sindromas ar plaučių arterijos tromboembolija, lèmé transudato kaupimąsi pleuros ertmejje. Jei skystis eksudatas, būtinas tolesnis jo tyrimas $[1,2,10,11]$

Maža pleuros skysčio gliukozès koncentracija $(<3,3 \mathrm{mmol} / \mathrm{l})$ ir mažas pleuros skysčio $p H(<7,3)$ rodo vieną iš keturių dažniausių patologinių būkliụ: TB, neoplaziją, reumatoidinị artritą ar plaučių uždegimą $[1$, $2,8]$.

Svarbu nustatyti pleuros skysčio $\alpha$ amilazès aktyvumą, mat padidejęs aktyvumas (> $100 \mathrm{U} / \mathrm{l}$ ) ar didesnis nei 1 pleuros skysčio ir kraujo serumo amilazès santykis būna sergant kasos ligomis, neoplazija, plyšus stemplei, dèl kitų retų priežasčių (plaučių uždegimo, nutrūkusio negimdinio néštumo, hidronefrozès, kepenų cirozès) [1, 2, 8].

Padidejusi karcinoembrioninio antigeno koncentracija pleuros skystyje leidžia įtarti neoplaziją, tačiau tyrimo jautrumas nedidelis (40 proc.), o specifiškumas (90 proc.) nepakankamas neoplazijai diagnozuoti [8, 12, 13].

Pleuros skysčio citologinis tyrimas itin svarbus piktybiniam pleuritui diagnozuoti. Itvairių tyrèjų duomenimis, citologinio tyrimo jautrumas svyruoja tarp 40 ir 90 proc. [1, 2, 14]. Tyrimo jautrumas priklauso nuo morfologinio naviko tipo, ląstelių skaičiaus tepinèlyje, tyrimo metodo, citologo patirties [2]. Remiantis literatūros duomenimis, 2 lentelèje nurodoma pirminio naviko lokalizacija esant piktybiniam pleuritui. Pirminè lokalizacija nenustatoma $5-12$ proc. piktybinio pleurito atvejų [4]. 
Pleuros eksudato neutrofilija (neutrofilai sudaro daugiau kaip 50 proc. visu leukocitų) būdinga plaučiu uždegimui, pleuros empiemai, kasos uždegimui, podiafragminiam pūliniui, plaučiu arterijos tromboembolijai, ankstyvos stadijos TB [1, 2, 4, 8, 9].

Padidèjęs skaičius limfocitu (limfocitai sudaro daugiau kaip 50 proc. visu leukocitų) pleuros eksudate dažniausiai nustatomas esant neoplazijai ar TB, bet galimas ir plaučių arterijos tromboembolijos, virusinès ligos, chilotorakso, sarkoidozès, geltonųju nagų sindromo, reumatiniu ligų, asbesto sukelto pleurito atvejais. Klinikinejje praktikoje nustačius padidejusị skaičiu limfocitu pleuros skystyje pirmiausia reikia itarti dvi patologijas: TB ir neoplaziją $[1,4,8,9,15]$.

Pleuros eksudato eozinofilija diagnozuojama, kai pleuros skystyje eozinofilai sudaro daugiau kaip 10 proc. visu leukocituc. Ji nustatoma 1-15 proc. visu eksudacinio pleurito atvejų [16]. Pleuros skysčio eozinofilija susijusi su pneumotoraksu, asbestoze, plaučių infarktu, sarkoidoze, kolagenoze, Čargo-Štrauso (Churg-Strauss) sindromu, hemotoraksu. Be to, eozinofilai pleuros skystyje kaupiasi dèl vaistu poveikio (dantroleno, bromokriptino, nitrofurantoino ir kt.), parazitinių ligų (paragonimiazès, amebiazès, echinokokozės, askaridozès), grybelinių ligu (histoplazmozès, aktinomikozès, kokcidiomikozès), TB, neoplazijos, chilotorakso, geltonụju nagu sindromo atvejais. Dažniausiai pleuros skysčio eozinofiliją lemia oro ar kraujo buvimas pleuros ertmejje (trauma, pleuros ertmès punkcija ir kt.) [2, 4, 8, 9, 16]. Mūsų duomenimis, neoplazija buvo 21 proc. eozinofiliniu pleurito atvejų priežastis $[8,9]$. Pleuros skysčio eozinofilijos priežastis, nesant oro ir kraujo pleuros ertmèje, dažnai yra neaiški, tačiau ji nebūdinga tuberkulioziniam pleuritui [17].

Pleuros skysčio makrofagai yra kilę iš kraujo monocitu ar mezotelio ląstelių. Makrofagu monocitų padaugèja sergant ịvairiomis ligomis, todèl jụ diagnostinè reikšmė menka. Bazofilu ir plazminiu ląstelių diagnostinè reikšmė yra ribota. Didelis skaičius bazofilu, plazminių ląsteliụ būdingas leukemijai, mielominei ligai. Nedidelis skaičius plazminiụ ląsteliụ pleuros skystyje diagnostinès reikšmès neturi [1].

Pleuros mezotelio ląstelių diagnostiné reikšmè svarbesnè dviem aspektais. Pirma, tuberkulioziniam pleuritui nebūdingas didelis skaičius mezotelio ląsteliụ skaičius [2]. Dažniausiai tuberkuliozinès kilmès pleuros skystyje mezotelio ląstelès neviršija 5 proc., bet jų nebuvimas nepaneigia TB diagnozès. Mažas skaičius mezotelio ląsteliu susijęs su fibroziniais pleuros pokyčiais, o jụ nustatoma ne tik esant tuberkulioziniam pleuritui, bet ir komplikuoto parapneumoninio pleurito atveju, po pleurodezès [1]. Antra, kartais pleuros skysčio mezotelio ląsteles, ypač reakcines formas, sunku atskirti nuo véžinių ląstelių, o pastarąsias nuo mezoteliomos [1, 2]. Atskirti gali padèti imunocitocheminès reakcijos ar elektroninè mikroskopija [18].

Bendrojo leukocitu skaičiaus pleuros skystyje diagnostinė reikšmé nedidelè. Daugumos transudatų leukocitų skaičius mažesnis nei $1000 / \mathrm{mm}^{3}$, o daugumos
2 lentelè. PIRMINIO NAVIKO LOKALIZACIJA ESANT PIKTYBINIAM PLEURITUI LITERATŨROS DUOMENIMIS $(p>0,05)$

\begin{tabular}{lcc}
\hline Pirminis navikas & Piktybinis pleuritas & \\
\hline & $\mathrm{n}=1783(35)$, proc. & $\mathrm{n}=472(59)$, proc. \\
\hline Plaučiai & 36 & 35,6 \\
\hline Krūtis & 25 & 14,8 \\
\hline Limfoma & 10 & 15,9 \\
\hline Kiaušidès & 5 & 8,1 \\
\hline Skrandis & 2 & 5,9 \\
\hline Kiti & 15 & 9,5 \\
\hline Neaiški lokalizacija & 7 & 10,2 \\
\hline
\end{tabular}

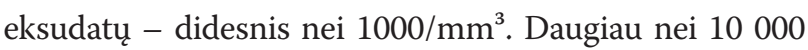
leukocitụ $\mathrm{mm}^{3}$ būdinga plaučiu ir kasos uždegimui, plaučiu arterijos tromboembolijai ir kitoms ligoms [1].

Kad pleuros skystis atrodytu kraujingas, jame turi būti $5000-10000 / \mathrm{mm}^{3}$ eritrocitų. Jei pleuros skysčio yra apie $500 \mathrm{ml}$, o periferiniame kraujyje eritrocitu $5 \mathrm{mln} / \mathrm{mm}^{3}$, tai i pleuros skysti patekus $1 \mathrm{ml} \mathrm{kraujo}$ jis atrodo kraujingas. Taigi hemoraginis skystis neturi didelès diagnostinès reikšmès. Daugiau kaip 15 proc. transudatu ir daugiau 40 proc. eksudatu yra kraujo atspalvio [1].

Pleuros skysčio hematokritas, didesnis nei 50 proc. periferinio kraujo hematokrito, būdingas hemotoraksui. Hemotorakso priežastis - kraujagyslès plyšimas ir kraujavimas ì pleuros ertmę. Dažniausiai hemotoraksą sukelia buka ar kiaurinè trauma, kuri gali būti ir jatrogeninè. Retai hemotoraksas gali būti savaiminis, dažniausiai dèl savaiminio hemopneumotorakso ir gydymo antikoaguliantais. Kitos priežastys: pirminè koaguliopatija, sisteminių ar plaučių kraujagyslių erozija dèl naviko ar egzostozès, plaučiu infarktas dèl embolijos ar nekrozinès plaučiu infekcijos, plaučiu arterinès-veninès jungties, endometriozé, sisteminè raudonoji vilkligé, sarkoidozé, nusileidžiančiosios aortos plyšimas, kartais kraujavimas gali būti podiafragminis [1,2].

Pleuros skysčio mikrobiologinis tyrimas - svarbus diagnozuojant pleuros empiemą. Plaučiu uždegimas yra dažniausia pleuros empiemos priežastis $[1,8,19]$. Daugeliu atvejų nepneumoninè empiema būna jatrogeninè, dažniausiai pulmektomijos ar kitų chirurginiu procedūrų komplikacija: 21 proc. sukelia krūtinès operacijos, apie 2 proc. - pleuros ertmés punkcija. Retai pleuros empiemos priežastis gali būti podiafragminè infekcija - dažniausiai po pilvo operacijų [3].

Tuberkuliozinio pleurito diagnostika. Tuberkuliozinis pleuritas diagnozuojamas nustačius tuberkuliozès mikobakterijų (TM) pleuros skystyje ar pleuros bioptate, kazeozinę granulomą pleuros bioptate, TM skrepliuose ir granulomu pleuros bioptate $[1,2,20]$.

Tuberkuliozini pleuritą reikia itarti, jei pleuros skysčio eksudate vyrauja limfocitai (daugiau kaip 50 proc. visų leukocitų), nesvarbu, ar tuberkulino méginys teigiamas ar neigiamas $[1,8,9]$. Neutrofilai yra pirmoji ląstelè, kuri sureaguoja i $\mathrm{TM}$ antigeną, tačiau po 7 paru pleuros skystyje jau vyrauja limfocitai [1].

Skrepliụ pasèliai būna teigiami $30-50$ proc. ligonių, sergančiu plaučiu ir pleuros $\mathrm{TB}$, bet tik 4 proc. - 
3 lentelè. KLINIKINIS PLAUČIU ARTERIJOS TROMBINÉS EMBOLIJOS TIKIMYBÉS VERTINIMAS [25]

\begin{tabular}{lc}
\hline Rizikos veiksnys & Balai \\
\hline Amžius > 65 metų & 1 \\
\hline $\begin{array}{l}\text { Buvusi giliųjų venų trombozė ar plaučių arterijos } \\
\text { trombinė embolija }\end{array}$ & 3 \\
\hline $\begin{array}{l}\text { Operacija ar apatinių galūnių lūžiai } 1 \text { mènesio } \\
\text { laikotarpiu }\end{array}$ & 2 \\
\hline Neoplazija & 2 \\
\hline Vienos kojos skausmas & 3 \\
\hline Kraujo atsikosejjimas & 2 \\
\hline Širdies susitraukimų dažnis - 75-94 k. per min. & 3 \\
\hline Širdies susitraukimų dažnis > 95 k. per min. & 4 \\
\hline $\begin{array}{l}\text { Skausmingos čiuopiamos giliosios kojų venos } \\
\text { ar patinusi viena koja }\end{array}$ & Balų suma \\
\hline Klinikinė tikimybe & $0-3$ \\
\hline Maža & $4-10$ \\
\hline Vidutinė & $\geq 11$ \\
\hline Didelė & \\
\hline
\end{tabular}

sergančių izoliuotu tuberkulioziniu pleuritu. Apie 50 proc. atvejų pleuros TB pasireiškia kaip pirminè liga nesant kitų organų pažeidimo. Skysčio pleuroje dažniausiai atsiranda dèl padidejjusio jautrumo TM baltymams. Pačių bakterijų pleuros skystyje nustatoma retai, dèl to pleuros skysčio ir bioptato pasèlis daugeliu atveju būna neigiamas [1].

Pleuros TB diagnozuoti pradèta ieškoti naujų metodų. Polimerazès grandininès reakcijos (PGR) tyrimas atliekamas greitai. Metodo jautrumas naudojant ịvairias genomines sekas yra 20-81 proc., o specifiškumas 78-100 proc. Kadangi PGR tyrimo metodika sudètinga, klinikineje praktikoje jis taikomas retai [1]. Antimikobakterinių antikūnų nustatymas pleuros skystyje nepakankamai jautrus ir specifiškas tyrimas, todèl TB diagnozuoti nerekomenduojamas [1, 21].

Siekiant anksti diagnozuoti pleuros TB, pradèti tirti biocheminiai žymenis: pleuros skysčio adenozindezaminazès (ADA) aktyvumas, gama interferonas (INF $\gamma$ ) ir lizocimas [1, 2].

Literatūros duomenimis, tirtų ADA jautrumas tuberkuliozinio pleurito atvejais yra 91-100 proc., o specifiškumas - 81-94 proc. Teigiamo ir neigiamo rezultato prognozinè vertè - atitinkamai $84-93$ proc. ir $89-100$ proc. 5,7 proc. atvejų nustatomi klaidingai teigiami rezultatai dèl plaučių véžio, limfomos, plaučių uždegimo, pleuros empiemos, mezoteliomos, reumatoidinio artrito, sisteminès raudonosios vilkligès [15, 22].

Nors ADA-2 aktyvumo pleuros skystyje tyrimas yra jautrus (99 proc.) ir specifiškas (93 proc.) diagnozuojant tuberkuliozini pleuritą, L. Valdes su bendradarbiais, išnagrineję 350 tuberkuliozinių pleurito atvejų, nenustatè statistiškai reikšmingai skirtumo tarp ADA-2 ir bendrojo ADA aktyvumo, todèl ADA-2 aktyvumo tyrimas pleuros skystyje neprigijo klinikineje praktikoje $[1,15,22]$.

Daugelio tyrèjų nuomone, pleuros skysčio tyrimas BACTEC metodu šiuo metu yra jautriausias ir greičiausias pleuros skysčio TM kultūrų auginimo meto- das [1]. Mūsų duomenimis, pleuros skysčio mikrobiologinis tyrimas BACTEC metodu (45 proc.) buvo jautresnis diagnozuojant tuberkuliozini pleuritą nei tepinèlis, dažytas Cylio-Nilseno būdu ( 4,5 proc.) ( $\mathrm{p}<$ 0,05). Nors pleuros skysčio tepinèlio, dažyto Cylio-Nilseno būdu, tyrimas yra greitas, tačiau mažai jautrus, o neigiamas tyrimo rezultatas nepaneigia pleuros $\mathrm{TB}$ [8]. Pleuros skysčio tyrimas BACTEC metodu nèra greitas (vidutiniškai 11 dienų), tačiau ne tik padeda diagnozuoti TB, bet ir leidžia, išskyrus grynąsias TM kultūras, nustatyti jautrumą vaistams nuo TB [8]. Tai yra svarbu, nes Lietuva pagal vaistams atsparios TB paplitimą yra viena pirmaujančiuc pasaulyje. Pirminis TM atsparumas vaistams Lietuvoje siekia 24,4 proc., o igytas gydytų ligonių grupeje - 32,4 proc. [23]. Kai TB diagnozuoti taikomas tik pleuros skysčio ADA aktyvumo tyrimas, ligoniams, sergantiems vaistams atsparia TB, iškyla potenciali grèsmè, kad nežinant TM jautrumo vaistams rezultatų jie gali būti gydomi netinkamai. Taigi pleuros skysčio ADA aktyvumo tyrimas negali pakeisti pleuros skysčio pasèlių [8].

Pleuros skystis plaučiu arterijos trombinès embolijos atveju gali būti tiek transudatas, tiek eksudatas. Nèra specifinių pleuros skysčio tyrimų, leidžiančių ịtarti ar diagnozuoti šią patologiją. Atrankinis diagnostinis testas angiografinei kompiuterinei tomografijai galètų būti D-dimerų tyrimas periferiniame kraujyje. Šis tyrimas pasižymi dideliu jautrumu, tačiau jo specifiškumas nèra didelis. Jei D-dimeru koncentracija ar aktyvumas kraujyje normalus ir klinikinè plaučių arterijos trombinès embolijos tikimybè yra maža (3 lentelè), ligoniui angiografinè kompiuterinè tomografija netaikytina [24].

\section{BRONCHOSKOPIJA}

Bronchoskopija pleuros skysčio diferencinei diagnostikai yra svarbi šiais atvejais [26, 27]:

- krūtinès ląstos rentgenogramoje ar kompiuterinèje tomogramoje matyti plaučio infiltracija;

- atsikosejjama kraujo;

- skysčio pleuros ertmejje yra daug (daugiau nei trys ketvirtadaliai pleuros ertmès);

- tarpuplautis pasislinkęs i pleuros skysčio pusę.

\section{PLEUROS BIOPSIJA IR BIOPSINĖS MEDŽIAGOS TYRIMO VERTINIMAS}

Adatinè pasieninès pleuros biopsija pirmą kartą aprašyta 1955 metais ir dažniausiai buvo taikoma diagnozuojant tuberkuliozini pleuritą [1]. Iš pradžių pleuros bioptato audiniai naudoti tik histologiniam tyrimui ir jautrumas diagnozuojant tuberkuliozini pleuritą buvo 40-80 proc. $[1,2]$. Vèliau auginant pasieninès pleuros bioptato pasèlius ir atliekant histologini tyrima pasiektas 86-95 proc. diagnostinis jautrumas [15, 19]. Mūsų duomenimis, adatinès pasieninès pleuros biopsijos tyrimo jautrumas tuberkuliozès atveju -45 proc. Be to, pleuros bioptato histologinis tyrimas (specifinè granuloma) buvo jautresnis metodas nei pleuros bioptato pasėliai Liovenšteino-Jenseno terpèje [28]. Derinant 
pleuros skysčio mikrobiologini ir pasieninès pleuros adatinès biopsijos tyrimą diagnostinis jautrumas diagnozuojant tuberkuliozini pleuritą yra 95,45 proc. [8].

Piktybinis pleuritas diagnozuojamas nustačius naviko ląsteles pleuros skystyje ar navikinị audini pleuros bioptate. Pleuros skysčio citologinio tyrimo jautrumas diagnozuojant piktybini pleuritą svyruoja nuo 40 iki 90 proc., vidurkis - apie 62 proc. [1, 2, 4, 14]. Daugelis ekspertu pritaria, kad jei pradinis pleuros skysčio citologinis tyrimas yra neigiamas, ypač įtariant neoplaziją, reikia atlikti pasieninès pleuros biopsiją [1, 28].

Pleuros skysčio citologinis tyrimas yra jautresnis tyrimo metodas nei pasieninès pleuros biopsija [2, 4]. Pastarosios diagnostinis jautrumas dideja progresuojant ligai. Be to, darant "aklą" pasieninès pleuros adatinę biopsiją galima nepataikyti i naviko pažeistą pleuros vietą, svarbu ir procedūros atlikèjo patirtis [2, 4]. Šonkaulinès (pasieninès) pleuros biopsijos diagnostinis jautrumas yra nuo 39 iki 75 proc., vidurkis - apie 45 proc. $[2,4,28]$.

Derinant pasieninès pleuros biopsiją su citologiniu tyrimu pasiekiamas geresnis rezultatas nei taikant abu metodus atskirai. Atlikę perspektyvųji tyrimą, U. B. Prakash ir H. M. Reiman [2] nustatè, kad pleuros skysčio citologiniu tyrimu neoplazija patvirtinta 57,6 proc. tiriamųjų, pasienine pleuros adatine biopsija - 43 proc., o derinant abu tyrimo metodus $-64,7$ proc. tiriamụjų. Mūsų duomenimis, diagnozuoti pleuros limfomą pakanka pleuros skysčio imunokompetentinių ląsteliu tyrimo tèkmès citometru bei pasieninès pleuros adatinio bioptato imunohistocheminio tyrimo [8].

Piktybinès pleuros mezoteliomos atveju pasieninès pleuros adatiniai bioptatai būna gan nedideli ir dažniausiai nepakankami imunohistocheminiam tyrimui, elektroninei mikroskopijai [17, 29].

\section{TORAKOSKOPIJA IR TORAKOTOMIJA}

Kaip kito diagnostinès torakoskopijos indikacijos, matyti iš 4 lentelès.

Torakoskopijos jautrumas diagnozuojant neoplaziją ir TB yra apie 98 proc., o specifiškumas -100 proc. [2, 29]. Tačiau torakoskopija - invazinis tyrimo metodas, dažniausiai ji atliekama sukèlus bendrąją nejautrą, be to, ir pati aparatūra yra gan brangi, o mirtingumas, susijęs su torakoskopija, - 0,01-0,24 proc.

Manome, kad torakoskopija darytina, kai įtariamas piktybinis pleuritas, o pleuros skysčio citologinis tyrimas ir pasieninès pleuros adatinio bioptato histologinis tyrimas yra neigiami, taip pat itariant pleuros mezoteliomą. Tuberkulioziniam pleuritui diagnozuoti paprastai pakanka pleuros skysčio mikrobiologinio tyrimo ir (ar) pasieninės pleuros adatinio bioptato histologinio, ir (ar) mikrobiologinio tyrimo, todèl torakoskopiją tikslinga atlikti tik labai retais atvejais $[8,28]$.
4 lentelè. TORAKOSKOPIJOS INDIKACIJOS, HECKESHOM PLAUČIŲ LIGŲ KLINIKA, BERLYNAS [1]

\begin{tabular}{lccc}
\hline Indikacija & $\begin{array}{c}\text { 1971-1979 m. } \\
(\mathbf{n}=\mathbf{1 6 2 5}), \\
\text { proc. }\end{array}$ & $\begin{array}{c}\text { 1980-1988 m. } \\
(\mathbf{n}=\mathbf{1 5 1 9}), \\
\text { proc. }\end{array}$ & $\begin{array}{c}\text { 1995-1997 m. } \\
(\mathbf{n}=\mathbf{5 7 5}), \\
\text { proc. }\end{array}$ \\
\hline Pleuros skystis & 48 & 74 & 92,5 \\
\hline Neoplazija & 39 & 48 & 66 \\
\hline Tuberkulioze & 24 & 14 & 8 \\
\hline Kitos & 37 & 38 & 28 \\
\hline
\end{tabular}

\section{DIAGNOSIS OF PLEURAL DISEASES}

\section{ROLANDAS ZABLOCKIS \\ CLINIC OF CHEST DISEASES, ALLERGOLOGY AND RADIOLOGY VILNIUS UNIVERSITY}

Key words: pleura, pleural effusion, pleuritis, tuberculosis, neoplasm, biopsy. Summary. The most common pleural diseases, etiology of pleural effusions and diferential diagnosis of radiographic, pleural fluid, pleural biopsy examinations are discussed in this article.

\section{LITERATŪRA}

1. Light R.W. (Eds.) Pleural diseases // Williams \&Wilkins, Philadelphia. 2007. 427 p.

2. Loddenkemper R., Antony V.B. Pleural diseases // European Respiratory Monograph. 2002. Vol.7. N22. P.326.

3. Peek G.J., Moros S., Cooper G. Clinical review the pleural cavity // B.M.J. 2000. Vol.320. P.1318-1321.

4. Management of malignant pleural effusions. This official statement of the American Thoracic Society was adoted by the ATS board of directors // Am. J. Respir. Crit. Care. Med. 2000. Vol.162. P.1987-2001.

5. Zablockis R., Rubavičiūtè R., Valantinas J., Danila E. Pleuros skysčio ultragarsinio tyrimo reikšmè // Laboratorinè medicina. 2002.1(13).13-17.

6. Hierholzer J., Luo L., Bitter R.C., Stroszczynski C., et al. MRI and CT in the differential diagnosis of pleural disease // Chest. 2000. Vol.118. P.604-609.

7. Jimenez J.A., Charterina S.A., Paya J.S., Latorre F.F., Sanchez S.G., Llorens M.L. Evaluation of CT findings for diagnosis of pleural effusions // European Radiology. 2000. Vol.10. N4. P.681-690.

8. Zablockis R. Pleuros skysčio tyrimo metody diagnostinè vertè. Daktaro disertacija. Vilniaus universitetas, 2003.

9. Zablockis R., Nargèla R. Pleuros skysčio citologinio tyrimo diagnostinè reikšmè // Medicina. 2002.38(12).1171-1178.

10. Zablockis R., Vitkus D. Ligth'o kriteriju ir kraujo serumo-pleuros skysčio albumino gradiento reikšmé pleuros skysčio trasnsudato ir eksudato diagnostikai // Vaiku pulmonologija ir alergologija. 2001. 4(1-2). P.1245-1248.

11. Zablockis R., Vitkus D. Pleuros skysčio transudato ir eksudato diagnostika // Laboratorinè medicina. 2003.4(8).34-37.

12. Light R.W. Tumor markers in undiagnosed pleural effusions // Chest 2004. 126. P.1721-1722

13. Porcel J.M.; Vives M.; Esquerda A., et al. Panel of Tumor Markers (carcinoembryonic antigen, cancer antigen 125 , carbohydrate antigen 15- 3 and cytokeratin 19 fragments) in pleural fluid for the differential diagnosis of benign and malignant effusions // Chest 2004. 126. P.1757-1763.

14. Antunes G., Neville E., Duffy J., Ali N. BTS guidelines for the management of malignant pleural effusions // Thorax 2003. 58(Suppl II). P. ii29-ii38.

15. Diacon A.H., Van de Wal B.W., Wyser C., et al. Diagnostic tools in tuberculous pleurisy: a direct comparative study // Eur Respir J 2003. 22. P. 589-591.

16. Martinez-Garcia M.A., Viedma E.C., Rodrigez P.J., Ramirez M.H., Tordera M.P., Moret F.S. Diagnostic utility of eosinophils in the pleural fluid // Eur. Respir. J. 2000. Vol.15. P.166-169.

17. Zablockis R. Pleuros skysčio eozinofilijos priežastys // Medicinos teorija ir praktika. 2008 - T. 14. N. 2. P.135-139.

18. Roberts F., Mc Call A.E., Burnett R.A. Malignant mesothelioma a comparison of biopsy and postmortem material by light microscopy and immunohistochemistry // J. Clin. Pathol. 2001. Vol.54. N.10. P.766-770.

19. Davies C.W.H., Gleeson F.V., Davies R.J.O. BTS guidelines for the management of pleural infection // Thorax 2003. 58. P.18-28.

20. Trajman A., Kaisermann M.C., Kritski A.L., et al. Diagnosing Pleural Tuberculosis // Chest 2004. 125. P.2366-2367.

21. Gupta U.A., Chhabra S.K., Hiraki A., et al. Diagnosing tubercular pleural effusions // Chest 2005. 127. P.1078-1079.

Kiti literatūros šaltiniai redakcijoje (iš viso 29). 